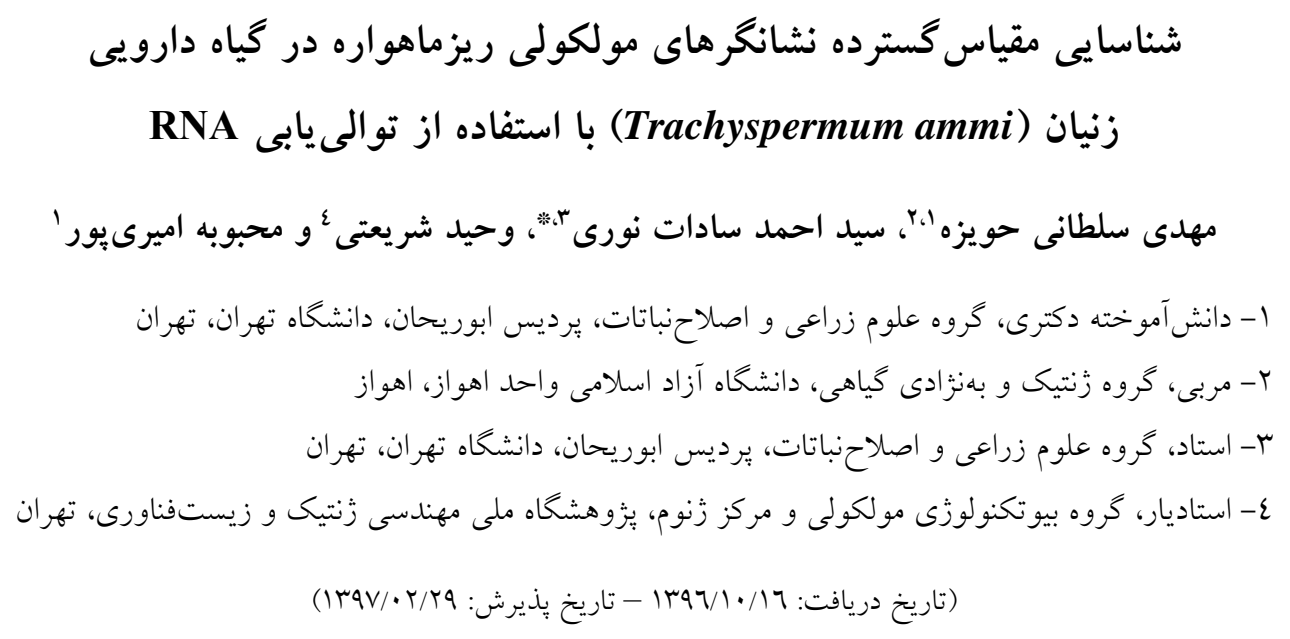

جكيده

كياه دارويى زنيان يك منبع غنى از تركيبات فعال دارويى و داراى اثرات مختلف دارويى است. با توجه به اينكه نشانكرهاى

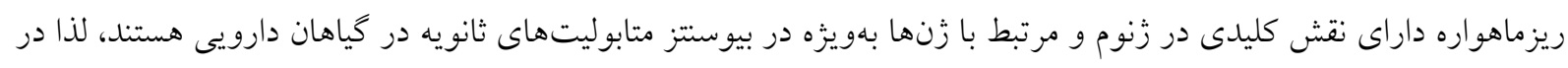

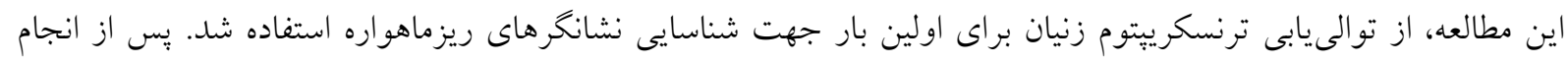

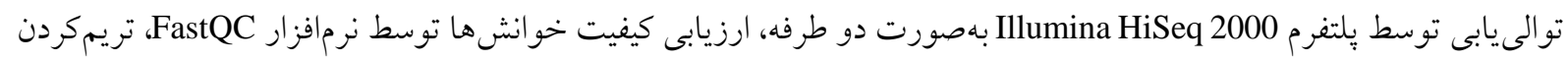

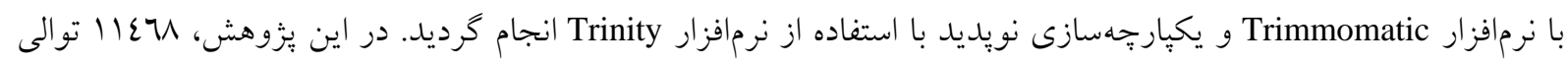

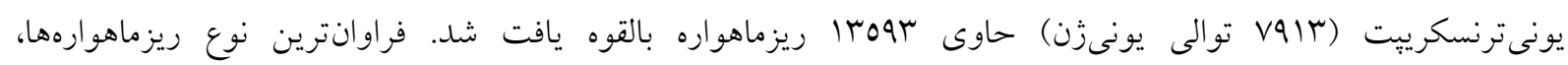

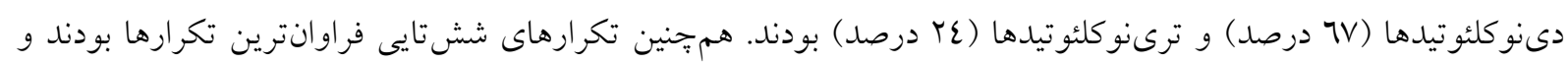

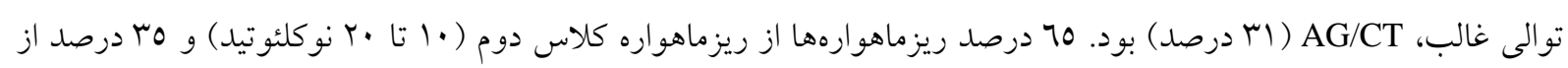

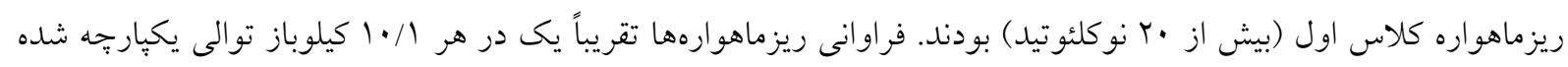

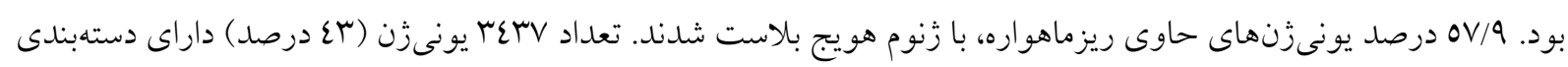

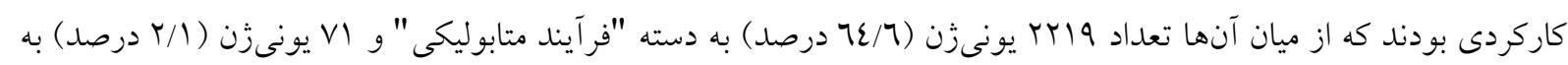

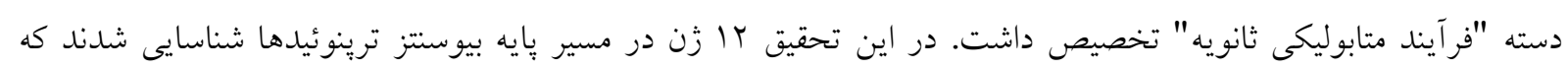

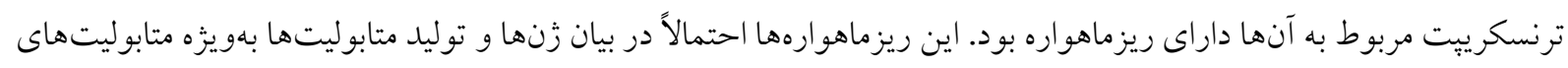

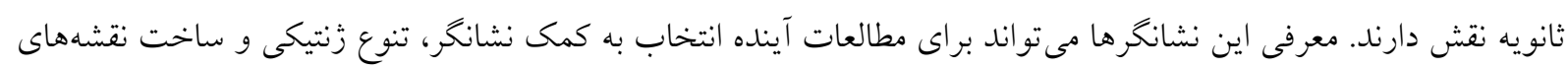
زنتيكى در اين كياه دارويى مورد بهرهبردارى قرار كيرد. وازگًان كليدى: آيياسه، ترينوئيدها، ترنسكرييتوم، متابوليتهاى ثانويه 
Sadati et al., 2016

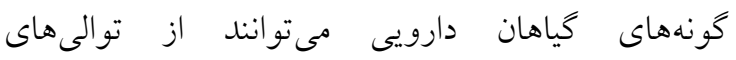

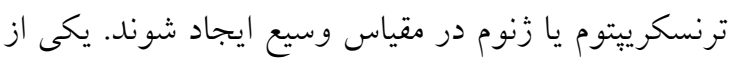

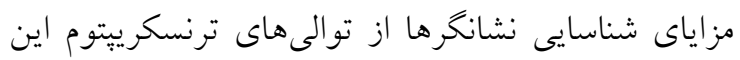

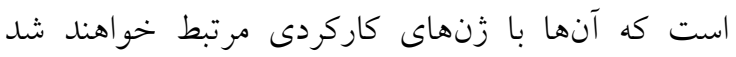
(Hiremath et al., 2011) نواحى كدكننده زنها، بيان و عملكرد زن را كنترل مى كنند

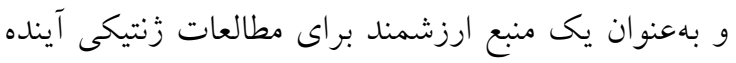
محسوب مىشوند (Li et al., 2002). ريزماهوارههاى

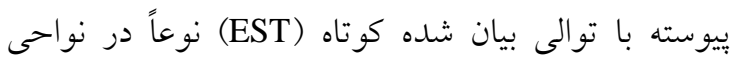

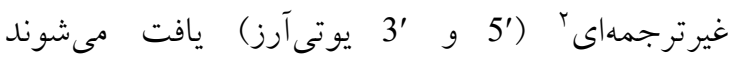
(Primmer, 2009) براى نشان دادن اثرات انتخاب (Vasemagi et al., 2005) داراى احتمال بالاترى (در مقايسه با نشانكرهاى زنتيكى

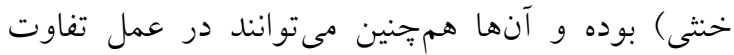
معنى دارى در تنظيم بيان و كاركرد زن ايجاد كنند. تا

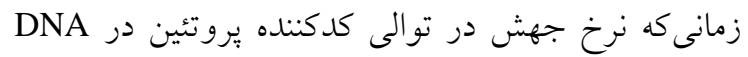
بايينتر از ساير توالىهاى DNA (مانند ايتترون و توالى تردي

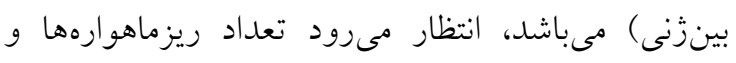

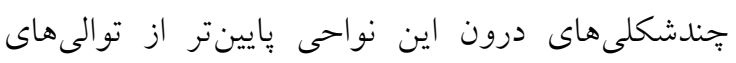

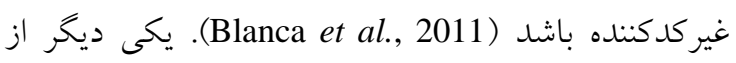

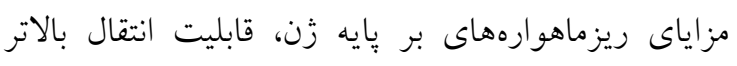

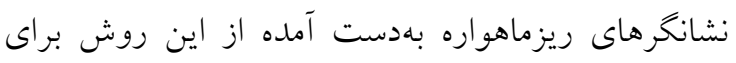

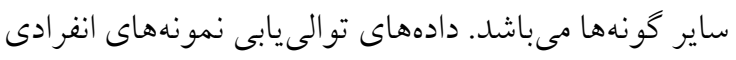

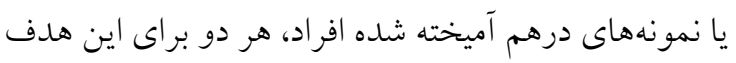
مناسب مىباشند (Futschik and Schlötterer, 2010). توالىيابى RNA مىتواند آناليز مسير متابوليكى كياهان

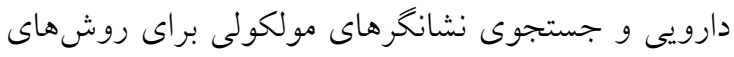

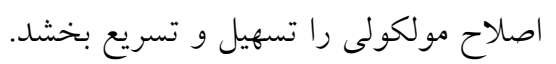
زنيان با نام علمى Trachyspermum ammi (مترادف: كه معمولاً بهعنوان Ajowan Carum copticum شده است در كشورهاى ايران، هند، پاكستان، افغانستان و مصر يراكنده مىباشد و در اين كشورها بهصورت وسيع

1- Next generation sequencing (NGS) 2- UTRs

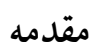

ريزماهوارهها (SSRs) توالىهاى تكرارى DNA بطول التا 7 نوكلئوتيد هستند كه بهصورت آرايههاى متوالى در تمام زنومهاى يوكاريوتى وجود دارند. در مقايسه با ساير انواع نشانخرهاى مولكولى، نشانخر هاى ريزماهواره مزياى زيادى دارند كه از آن جمله مىتوان به فراوانى بالا، توزيع تصادفى در كل زنوم، محتواى اطلاعاتى بالا، وراثت همبارز و تكراريذيرى اشاره نمود. اين نشانكرها در تحقيقات زنتيكى كياهان دارويى از براطلاعات ترين نشانخرهاى مولكولى و جنامنظوره هستند كه شناسايى آنها بسيار سخت و هزينهبر است (Li et al., 2002; Li et al., 2004). ارزيابى تنوع زنتيكى با استفاده از نشانگرهاى ريزماهواره يكى از

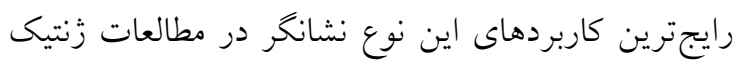
Shuorvazdi et al., 2014; Karimbeigi ) كياهى مىباشد . (et al., 2016

توالىيابى RNA با عمق زياد مىتواند مجموعه كل توالىهاى بيان شده موجود در بافت خاص، در نقطه زمانى مشخص و حتى رونوشتهاى كمياب را نشان دهد. بدين منظور اين روش مىتواند تصوير تقريباً كاملى از حوادث ترنسكريتوم در يك نمونه زيستى را نشان دهد ( Alagna et al., 2009; Barakat et al., 2009; Dassanayake et al., 2009; Bräutigam et al., 2011 كونههاى غيرمدل كه اطلاعات زنتيكى براى آنها وجود ندارد يا اطلاعات زنتيكى و دادههاى توالىيابى شدهى محدودى براى آنها وجود دارد، قابل استفاده مىباشد. بهويزه اينكه در اين روش تمركز توالىيابى، بهجاى توالىيابى كل زنوم تنها بر توالى يابى نواحى كدشونده است. يكى از مهمترين كاربردهاى توالىيابى نسل آينده' در زنتيك جمعيت، شناسايى نشانكر هاى مولكولى در مقياس

كسترده مىباشد (Strickler et al., 2012). تاكنون در گياهان دارويى مطالعات زيادى با استفاده از نشانكرهاى مولكولى بر روى تنوع زنتيكى صورت گرفته Farajpour et al., 2011; Bahmani et al., 2012; ) است 
بنابراين توالى يابى كسترده ترنسكرييتوم يا زنوم براى كياه

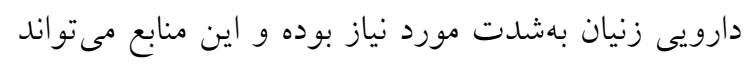

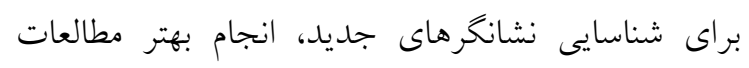
نشانكرهاى مولكولى، مكانيابى زن و مقايسه زنوم و غيره

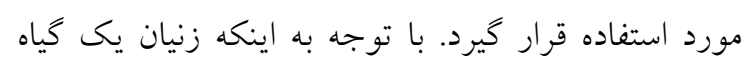

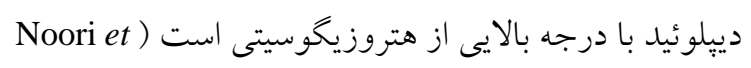

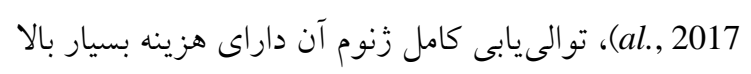

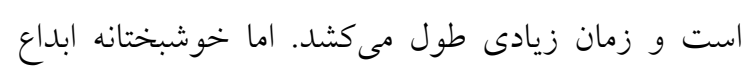
روش توالىيابى ترنسكرييتوم جايخزين مناسبى براى زئى

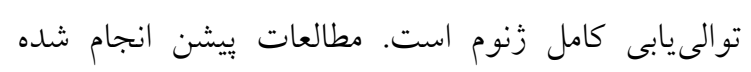
جهت بررسى تنوع زنتيكى زرميلاسم گياه دارويى زنيان،

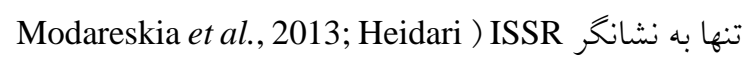
(et al., 2016 و نشانكر Sargazi, 2016) RAPD بوده است. لذا اين تحقيق جهت شناسايى مقياس گسترده

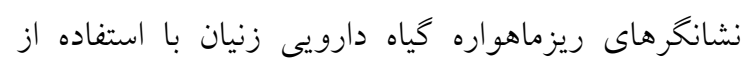

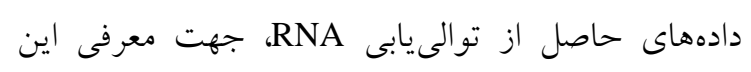

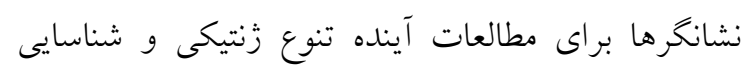

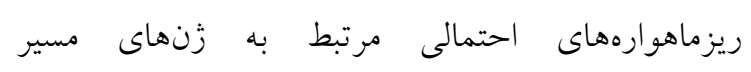

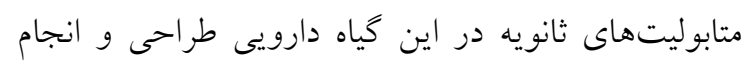
كرديده است.

\section{مواد و روشها} مواد كياهى: بذر دو اكوتيب مختلف كياه زنيان (اكوتيبٍ

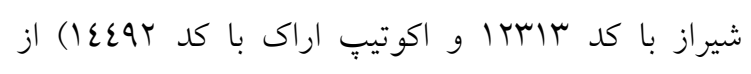
مؤسسه تحقيقات مراتع و جنگحل هاى كشور تهيه گرديد و

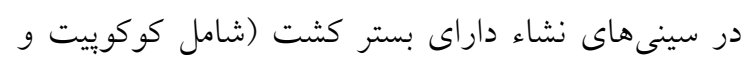

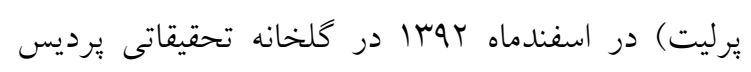

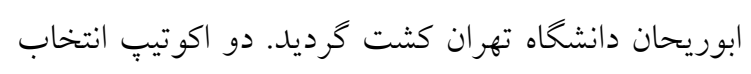

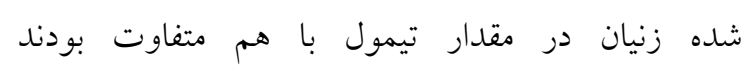
(Mirzahosseini et al., 2017)

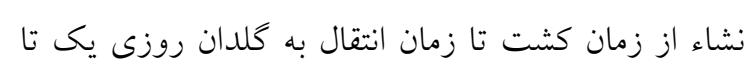

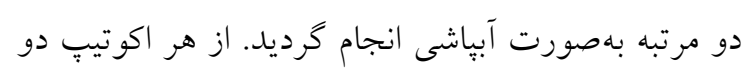

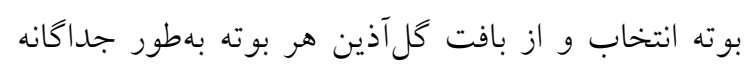
(ينج روز يس از كرده افشانى) نمونهبردارى شد. نمونها

1- Cytotoxic

2- Antifilarial
كشت مىشود. اين ميوه داراى خواصى همجهون محرك،

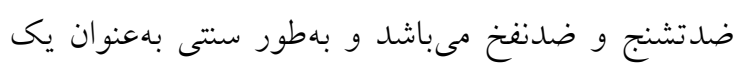

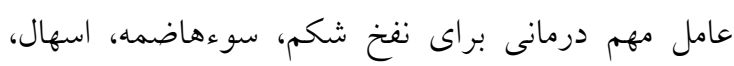

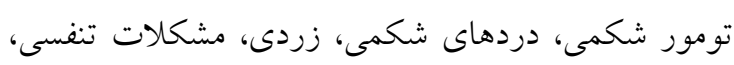

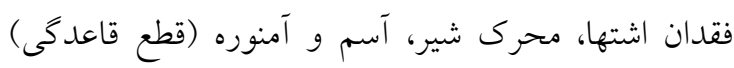

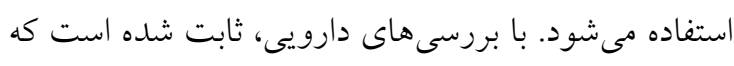

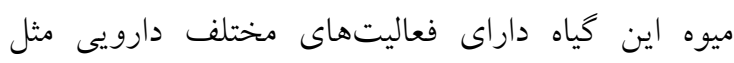

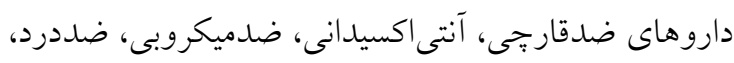

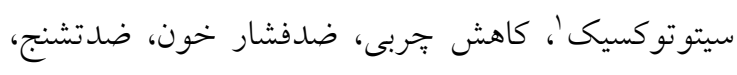

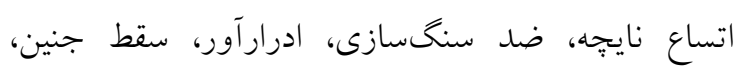
ضدسرفه، ضدانگل، ضدكرم و ض ضدفيلاريا؟ مى باشد.

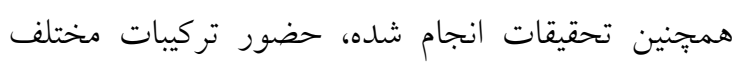

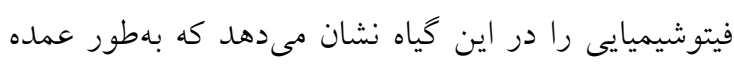

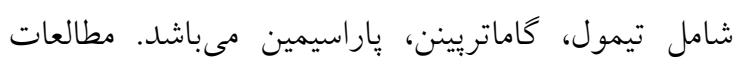
نشان مىدهد كه زنيان يك منبع مملو از تركيبات فعال دارويى و اثرات مختلف دارويى مىباشد، از اين رو، بيدا

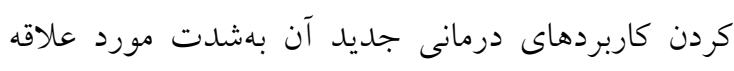
مجقيقن است ( Bairwa et al., 2012; Mirzahosseini et (al., 2017 علىرغم اهميت بالاى كياهان دارويى و بومى كشور از

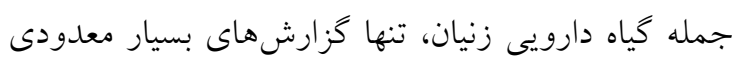

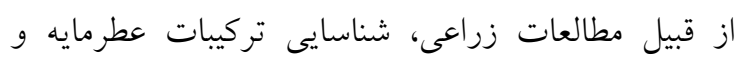

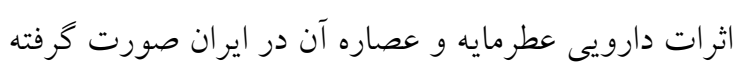
Mirzahosseini et al., 2017; Soltani Howyzeh et al., ) (2018b; Soltani Howyzeh et al., 2018a كزارشى در رابطه با شناسايى نشانكرهاى مولكولى اين خياه

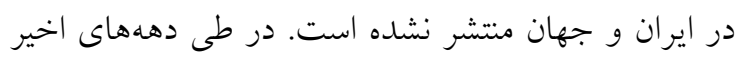

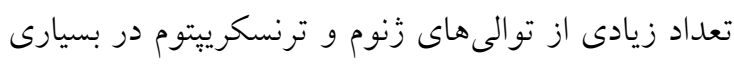
از موجودات مدل بهوجود آمده است (Fu et al., 2013). اين در حالى است كه براى گياه دارويى زنيان تاكنون تنها

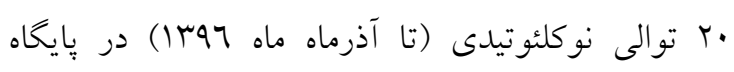

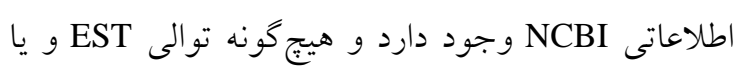
نشانگر ريزماهواره در اين گياه شناسايى نشده است. 
Trimmomatic شدند. يس از تريمكردن (Trimming)، نرمافزار FastQC براى ارزيابى مجدد ويزگىهاى كتابخانها و تأييد كارايى تريم كردن مورد استفاده قرار كرفت. خوانشهاى فيلتر شده با كيفيت بالا براى تحليلهاى بعدى مورد استفاده واقع

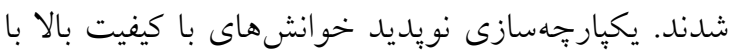
استفاده از نرمافزار Trinity (معرفى شده در تاريخ

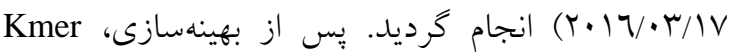

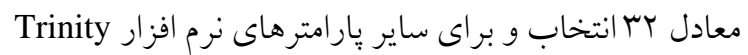
از تنظيمات استاندارد استفاده شد. توالىهاى بهدست آمده

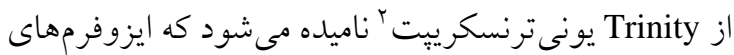
رونوشت مورد قبول را نشان مىدهد. كلاستر يونى ترنسكرييتها، يونىزن” ناميده مىشود كه زنهاى Grabherr et ) شناسايى شده مورد قبول را نشان مىدهد .(al., 2011 شناسايى نشانگرهاى ريزماهواره: نشانخرهاى ريزماهواره با استفاده از ابزار شناسايى ريزماهواره به نام MISA

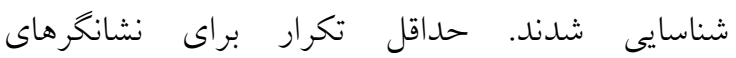
مونونو كلئو تيدى "ده" و بر اى نشانخرهاى دى -نو كلئو تيدى،

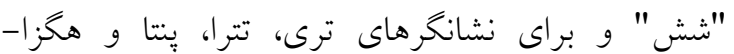

نو كلئو تيدى "ينج" قرار داده شد (Beier et al., 2017). تفسير كاركردى ْيونىزنهاى يكيارجه شده زنيان حاوى ريزماهواره: تفسير كاركردى ترنسكريتوم زنيان بهوسيله

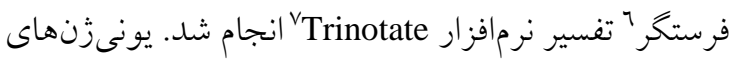

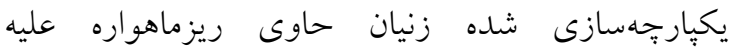
يروتئينهاى Non-redundant يايخاههاى اطلاعاتى NCBI، UniProt با استفاده از سرور محلى (Local Server) داراى ro7 كيخابايت حافظه موقت (RAM) و سى يى بو با •م هسته و سيستم عامل لينوكس بلاست شدند. مسيرهاى متابوليتى و

1- De novo assembly

2- Unitranscripts

3- Unigenes

4- http://pgrc.ipk-gatersleben.de/misa

5- Functional annotation

6- Pipeline

7- http://trinotate.github.io
در ازت مايع قرار گرفته و سبس به آزمايشگاه منتقل و تا زمان استخراج در فريزر •^-درجه سانتى گراد قرار گرفتند. استخراج RNA، ساخت كتابخانه و توالى يابى: RNA كل از نمونههاى گَآذين گياه دارويى زنيان بهوسيله بافر TRIzol reagent (Invitrogen) سازنده استخراج گرديد. نمونهاى RNA با هضمكننده تيمار شدند. كيفيت (TURBO DNaseI, Ambion) DNA و كميت RNA استخراج شده بهترتيب توسط زل آكاروز ا درصد و دستخاه نانودراب نورسنج مدل NanoDrop Thermo Scientific) 1000 spectrophotometer Qرديل. سبس بررسى بيشتر كيفيت توسط دستخاه Hørsholm, ) Agilent Technologies مدل Bioanalyzer Beijing Genomes Institute در موسسه (Denmark در كشور جين صورت گرفت و نمونههاى داراى (BGI) عدد RNA integrity number) RIN) بيش از ^ براى فرآيند توالىيابى انتخاب شدند. انتخاب دم يلىA، آماده سازى cDNA، اتصال آدايتورها، تشكيل كلاسترها و وليى توالىيابى در موسسه BGI و طبق توصيه شركت سازنده، با استفاده از كيت استاندارد ايليومينا انجام شد. توالىيابى توسط يُتفرم Illumina HiSeq بهصورت دوطرفه 2000 و طول · (Paired-end) خام جهار زنوتيٍ (دو بوته از هر اكوتيب) در آرشيو خوانش توالى NBCI sequence read archive (SRA) با شماره دسترسى SRR5137051 SRR137050، SRR5137053 و SRR5137052 ثبت شدند.

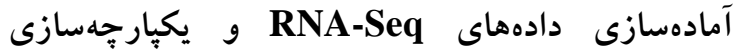
نويديد ا: در ابتدا كيفيت خوانشهاى خام بهدست آملده از تو الىيابى توسط نرمافزار FastQC سنجيده شد. سبس براى هر نمونه با توجه به نتايج كنترل كيفى، آدايتورهاو تو الىهاى كم كيفيت خوانشهاى خام با استفاده از نرمافزار 


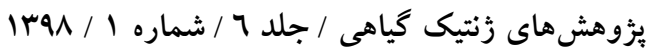

Citrullus lanatus ،(Lu et al., 2012) (فلفل قرمزز)

(هندوانه) (Guo et al., 2011)، (هنabiosa columbaria)

(گل داوودى) (Angeloni et al., 2011) و Polygonum (هفتبند زاينى) (Hao et al., 2012) بوده cuspidatum است در حالى كه ريزماهواره دىنو كلئوتيدى، تكرار غالب Chen et al., ) در Sonneratia alba) 2011)، Sesamum indicum P. notoginseng (Li et al., 2010) S. miltiorrhiza (Lin et al., 2011) G. Biloba و ود. (Luo et al., 2011) در اين بزّوهش، در مجموع ريزماهوارههاى با تكرارهاى ششتايى فراوانترين بودند و بس از آنها بهترتيب ريزماهوارههايى با هفت، ينج و هشت تكرار فراونترين

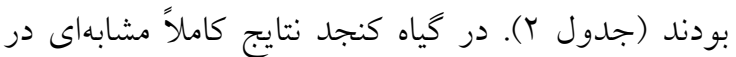
مei ( مورد بيشترين تكرارهاى ريزماهوارهها بهدست آمد إئ Dendrobium (et al., 2011 نيز ريزماهوارههاى با تكرارهاى ششتايى (officinale فراوانترين بودند و بس از آنها بهترتيب ريزماهوارههايى با ينج، هفت و هشت تكرار قرار گرفتند (Xu et al., 2017). فراوانترين ريزماهواره دىنوكلئوتيدى بهدست آمده در ترنسكرييتوم كياه دارويى زنيان AG/CT با سوبع تكرار (اس درصد) بود. در ميان ريزماهواره ترىنوكلئوتيدى نيز

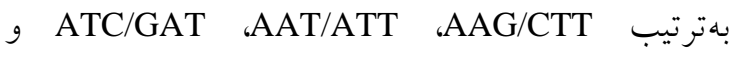
AGC/GCT (شكل Y). در كياهان اركيده دندروبيوم و كنجد نتايج مشابهى گزارش شده است. در اين گياهان نيز فراوانترين ريزماهواره دىنوكلئوتيدى AG/CT و وراوانترين

ريزماهواره ترىنو كلئوتيدى AAG/CTT بود ( 2011; Xu et al., 2017 (ين در حالى است كه در گياه

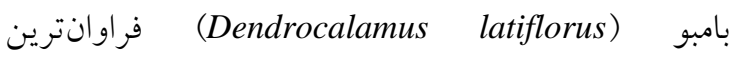
ريزماهواره دىنو كلئوتيدى AG/CT گزارش گرديد اما از سوى ديخر فراوانترين ريزماهواره ترىنوكلئوتيدى

CCG/CGG

1- Kyoto encyclopedia of genes and genome

2- KEGG automatic annotation server,

http://www.genome.jp/kegg/kaas

3- KEGG orthology

4- Single-directional best hit

5- http://wego.genomics.org.cn/cgi-bin/wego/index.pl
توصيف كاركردى براى هر يك از يونىزنهاى زنيان

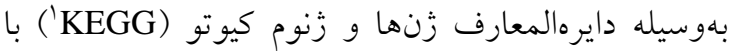
استفاده از سرور تفسير اتوماتيك KEGG بهنام KAAS براساس تخصيص عدد KO به به آنها بهدست آمد. تخصيص عدد KO بر اساس روش SBH' انجام گرفت. بايڤاه KAAS تفسير توالىهاى ارسال شده را با استفاده از شناسه هاى KO بهصورت خودكار انجام مى مهد. هر معادل يك گروه ارتولوگ از زنهايى است كه بهصورت مستقيم به يك ركورد در مسيرهاى بايخاه KEGG لينك شده (Moriya et al., 2007) و در نتيجه مرجع اطلاعات براى ارتباط دادن زنومها به سيستمزيستى است. طبقهبندى

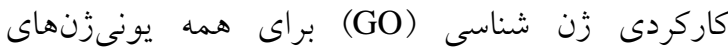

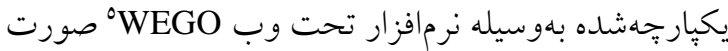

جستجوى نشانكرهاى ريزماهواره با استفاده از نرمافزار MISA

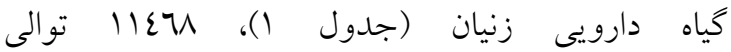

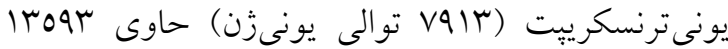
ريزماهواره بالقوه را نشان داد. ريزماهوارههاى دىنو كلئوتيدى فراوانترين ريزماهوارهها (در مجموعه داده اين يزوهش بودند. نتايج (دV)

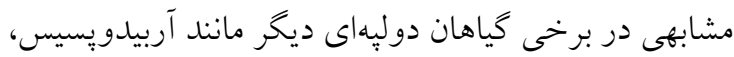

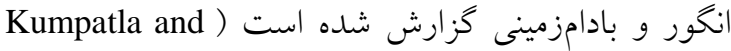
Mukhopadhyay, 2005 ). بِ از دىنو كلئو تيدها بهترتيب ترىنو كلئوتيدها (Y TYM علدد، ع درصد)، مونونو كلئوتيدها (7 درصد)، تترانو كلئوتيدها (Y درصد)، هخز انو كلئوتيدها (حدود يك درصد) و يُتانو كلئوتيدها (كمتر از يك درصد) قرار داشتند (شكل (1). تو الى هاى تكرارى كو تاه ترىنو كلئو تيدى، نوع غالبند الب تكرار در مجموعه داده ترنسكرييتوم A. tridentate (درمنه

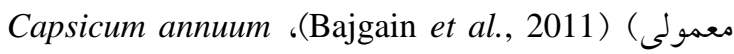


جدول ا- گزارش آمارى كانتيخهاى يكيارجه شده توسط نرم افزار Trinity

Table 1. Trinity assembly stats report of assembled contigs

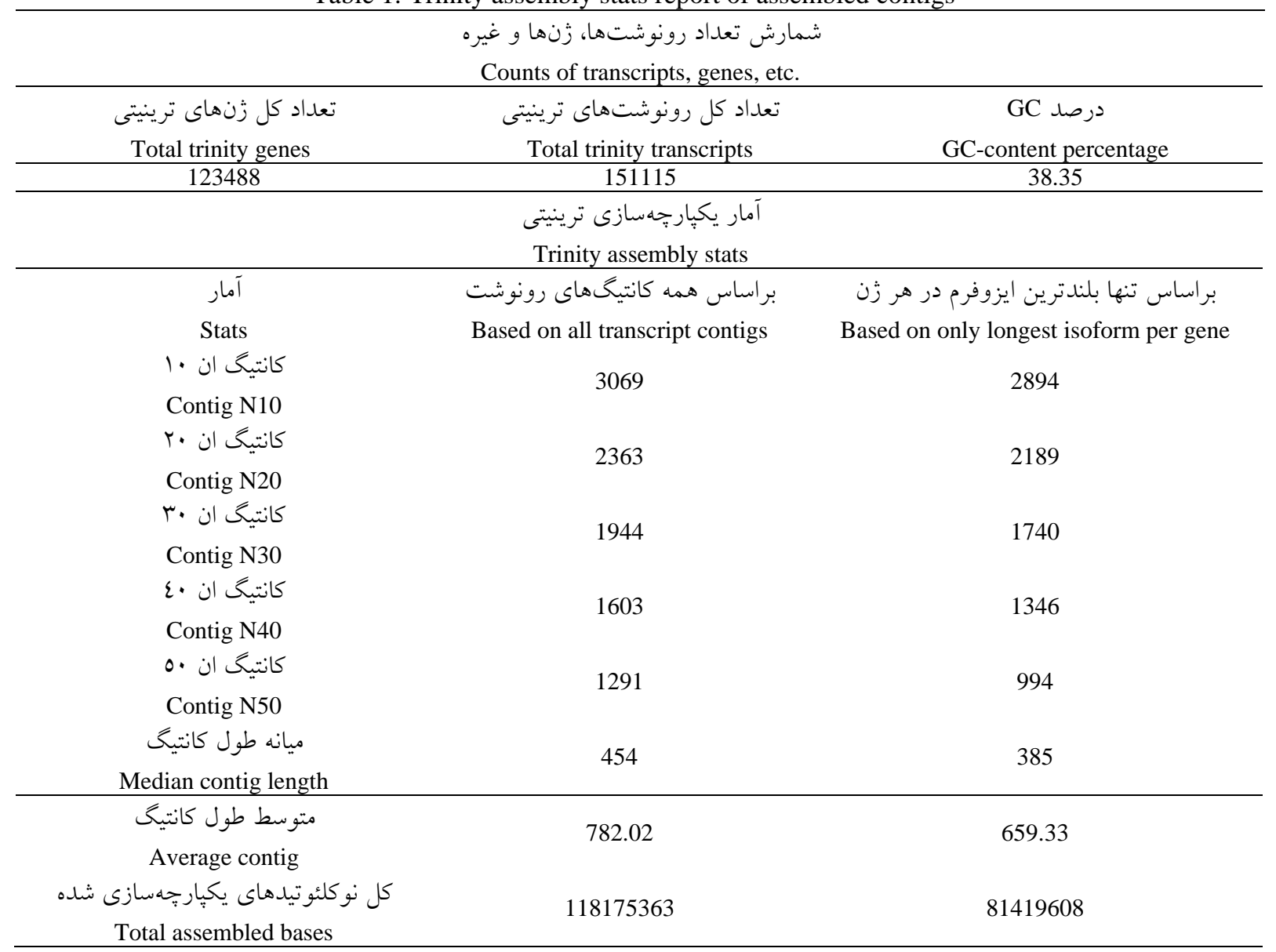

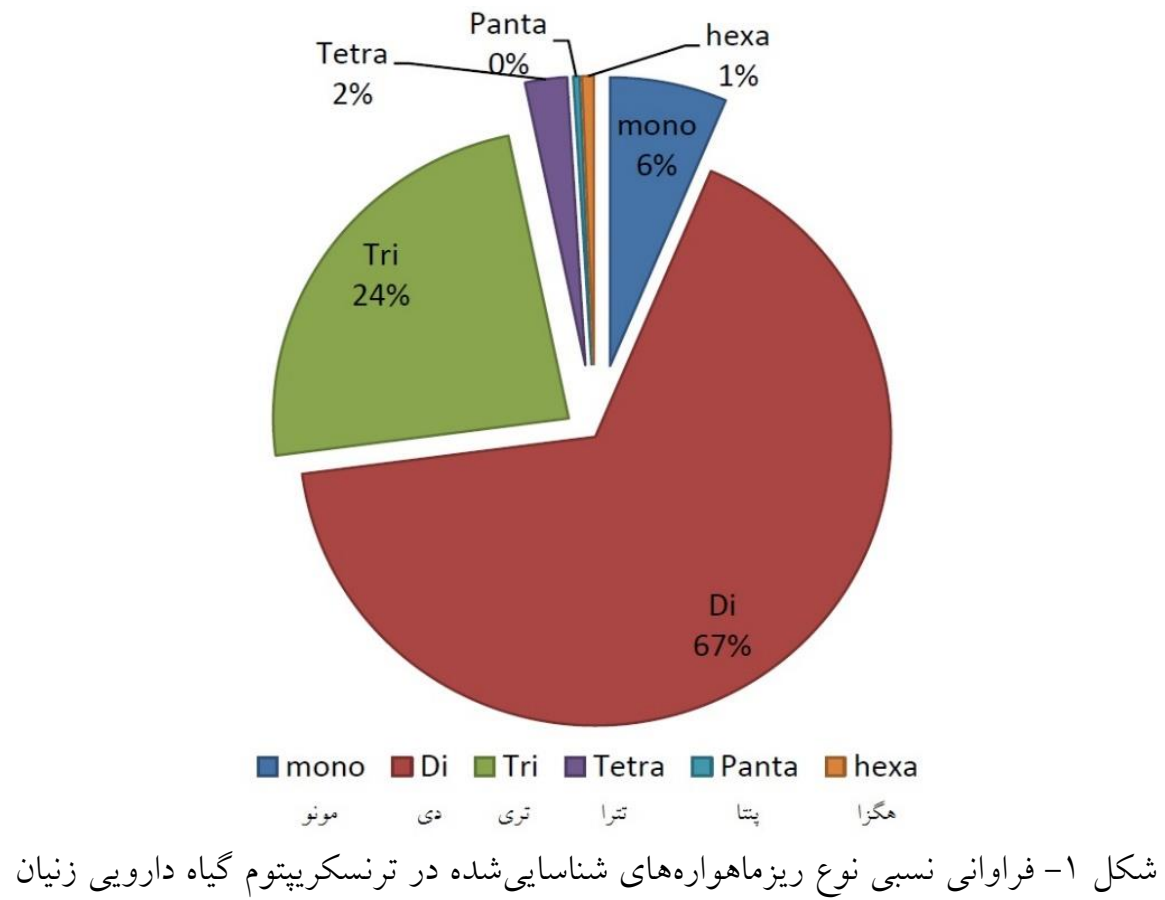

Figure 1. Relative frequency of microsatellite repeat types identified in medicinal plant transcriptome of $T$. ammi. 
أ جدول r- فراوانى ريزماهو ارهاى زنيان براساس نوع و تعداد تكرارها

Table 2. Frequency of T. ammi microsatellites based on type and number of repeats

\begin{tabular}{|c|c|c|c|c|c|c|c|}
\hline \multirow{3}{*}{ تكرار } & \multicolumn{6}{|c|}{$\begin{array}{c}\text { ध } \\
\text { Type }\end{array}$} & \multirow{3}{*}{$\begin{array}{l}\text { Total } \\
\text { Tجموع }\end{array}$} \\
\hline & مونو & دى & ترى & تترا & ينتا & هـزا & \\
\hline & Mono & $\mathrm{Di}$ & Tri & Tetra & Penta & Hexa & \\
\hline 5 & & & 1703 & 199 & 34 & 28 & 1964 \\
\hline 6 & & 2473 & 705 & 77 & 6 & 32 & 3293 \\
\hline 7 & & 1583 & 380 & 12 & 3 & 17 & 1995 \\
\hline 8 & & 1148 & 225 & 8 & 0 & 4 & 1385 \\
\hline 9 & & 785 & 35 & 7 & 0 & 3 & 830 \\
\hline 10 & 144 & 519 & 46 & 2 & 1 & 0 & 712 \\
\hline 11 & 176 & 445 & 23 & 0 & 2 & 0 & 646 \\
\hline 12 & 114 & 412 & 20 & 4 & 1 & 3 & 554 \\
\hline 13 & 110 & 195 & 33 & 0 & 0 & 0 & 388 \\
\hline 14 & 76 & 202 & 19 & 2 & 0 & 0 & 299 \\
\hline 15 & 62 & 180 & 6 & 1 & 0 & 0 & 249 \\
\hline 16 & 28 & 162 & 10 & 0 & 0 & 0 & 200 \\
\hline 17 & 36 & 162 & 6 & 0 & 0 & 0 & 204 \\
\hline 18 & 6 & 144 & 7 & 0 & 0 & 0 & 157 \\
\hline 19 & 12 & 141 & 6 & 0 & 0 & 0 & 159 \\
\hline$\geq 20$ & 106 & 494 & 88 & 0 & 0 & 0 & 608 \\
\hline $\begin{array}{l}\text { مجموع } \\
\text { Total }\end{array}$ & 870 & 9045 & 3232 & 312 & 47 & 87 & 13593 \\
\hline
\end{tabular}

تفسير كاركردى يونىزنهاى يكهيارجه شده زنيان حاوى

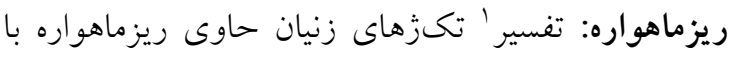

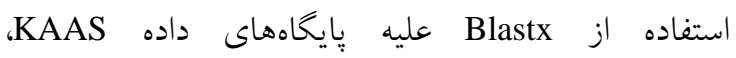

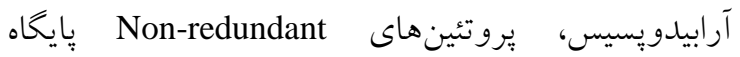
UniProt ،NCBI (19/T)

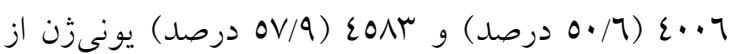

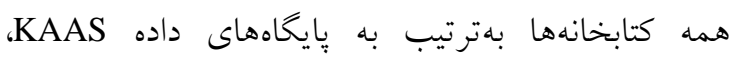

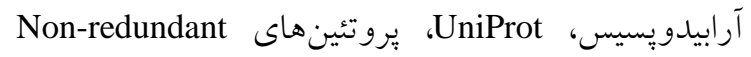

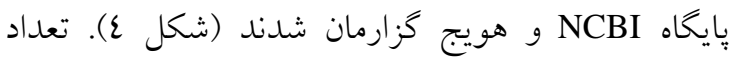
يونىزنهاى تفسير شده مشترى بين همه بإيخاههاى اطلاعاتى ع7عا بود (شكل ع). يونىزنهاى زنيان بهطور

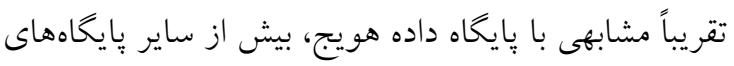

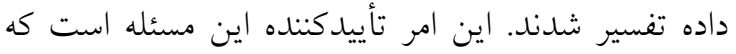

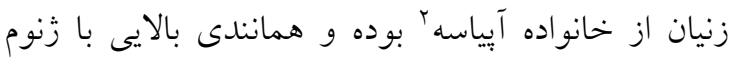

$$
\text { هويج دارد. }
$$

در ميان نشانكرهاى ريزماهواره شناسايى شده در زنيان، 70

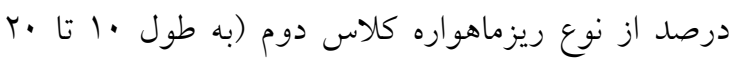
نو كلئوتيد) و 0r درصد از نوع ريزماهواره كلاس اول (به رتهارة

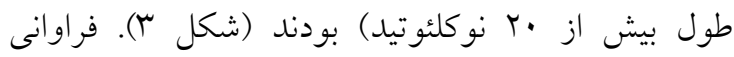

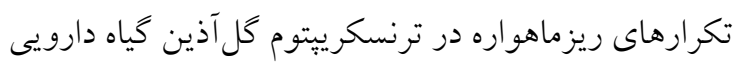

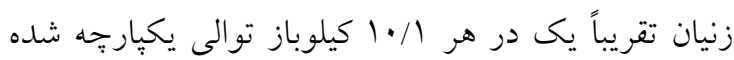

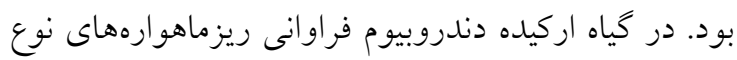
كلاس دوم ب9 درصد و فراو انى ريزماهو ارههاى نوع كلاس

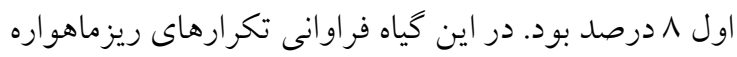

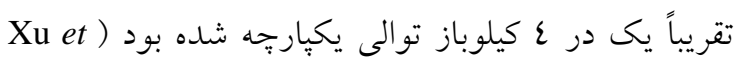

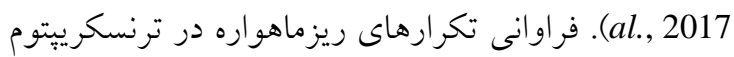

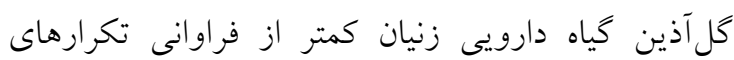

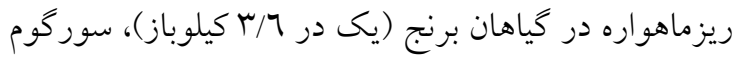

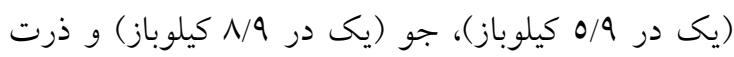

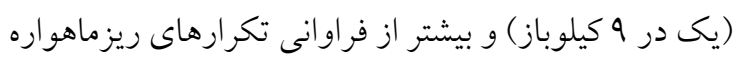

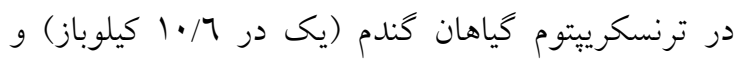
نيشكر (يك در 19/ • ا كيلوباز) بود (Parida et al., 2010). 
"يزوهش هاى زنتيك گياهى / جلد 7 / شماره | / 19 |

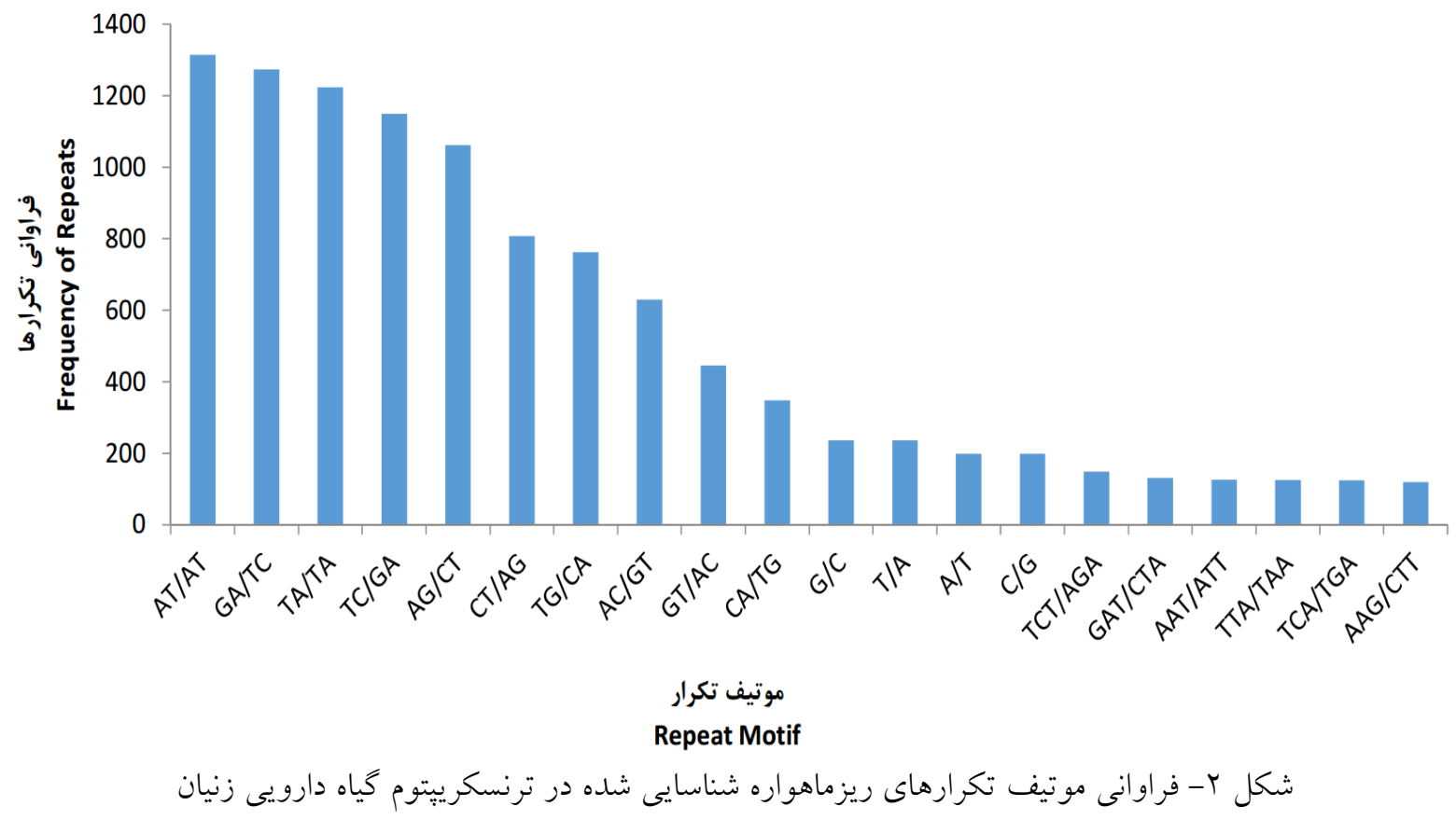

Figure 2. Frequency of microsatellite repeat motifs identified in medicinal plant transcriptome of T. ammi

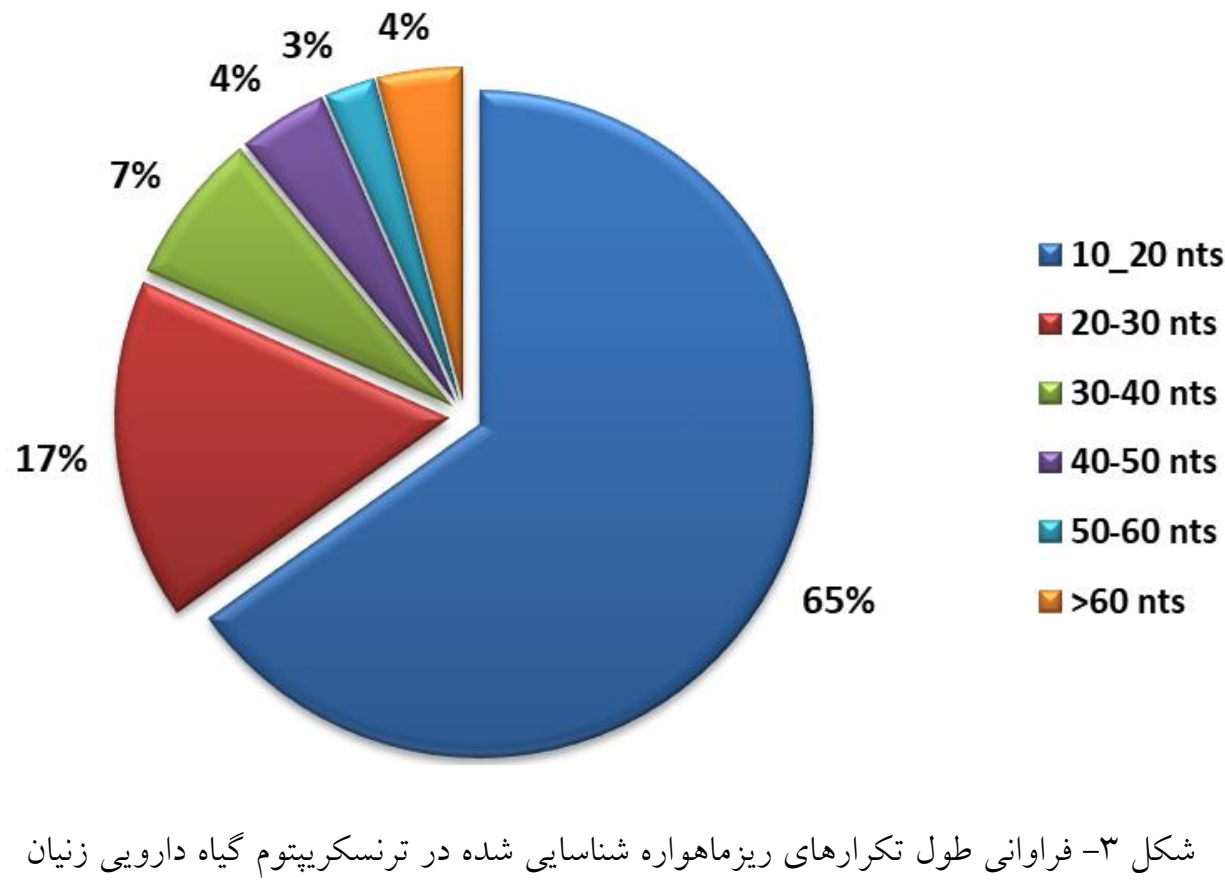

Figure 3. Frequency of microsatellite repeat length identified in medicinal plant transcriptome of T. ammi 


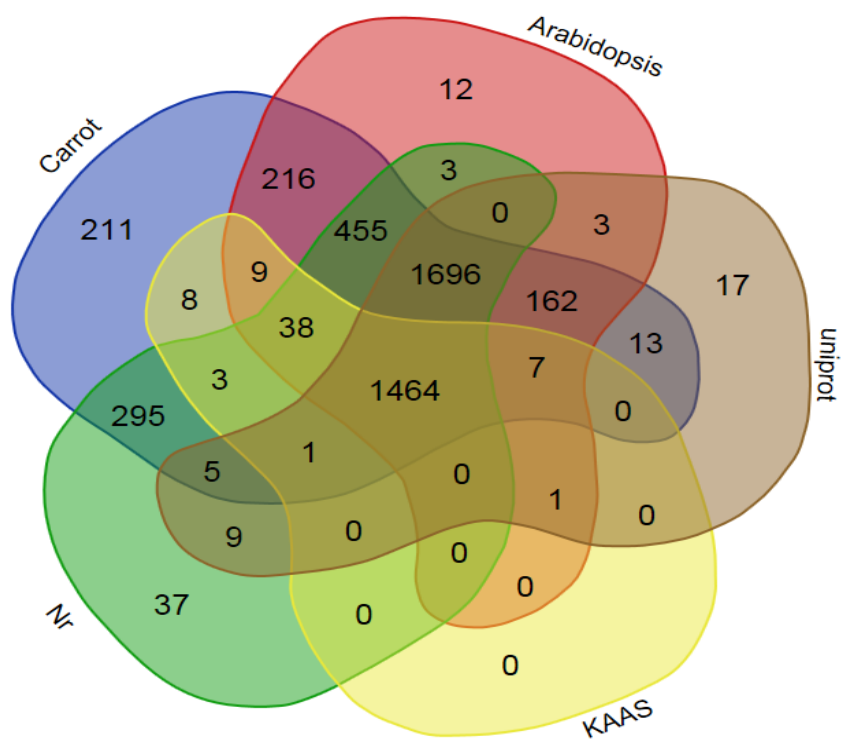

شكل ع- نمودار ون نتايج تفسير بلاست يونىزنهاى يكيار تهاسازى شده حاوى ريزماهواره عليه يايخاههاى اطلاعاتى مختلف Figure 4. Venn diagram of BLAST annotation results of assembled unigenes containing microsatellites against different databases

در Or دسته كاركردى طبقهبندى شد (شكل 7). دستجات "سلول"، " بخش سلولى"، " "اندامك"، "اتصال"، "فرو كافتى '"، "تنظيم زيستى "، "فرآيند سلولى "، "فرآيند

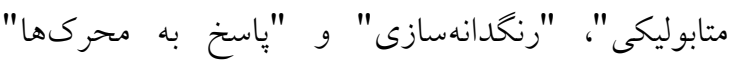
بيشترين درصد تخصيص را دارا بودند (شكل 7). در طبقه فرآيندهاى زيستى (BP) در ميان همه يونىزنهاى دستهبندى شده T/9 T/9 يونىزن (T/7 درصد) به دسته

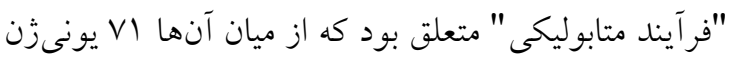

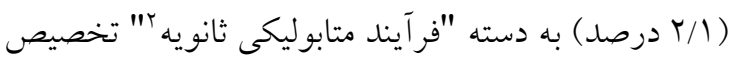
داشت. فراوانى تخصيص عبارتهاى GO مرتبط به فرآيند

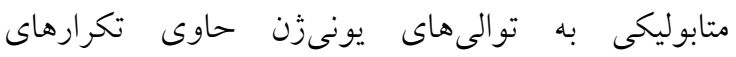
ريزماهواره مىتواند در شناسايى نشانخرهاى ريزماهواره مرتبط به بيان زنها و توليد و كنترل متابوليتها بهويزه متابوليتهاى ثانويه كمك كند. در مطالعه ريزماهوارههاى كياه كنجد نيز دسته "فرآيند متابوليكى" با ك/وس درصد كروه غالب در طبقه فر آيندهاى زيستى (BP) بود ( Wei et) (al., 2011 . نتايج مشابهى در مطالعه ريزماهوارههاى گياهان Chang et al., 2012; ) بادام و درخت كائو جو بهدست آمد

(Li et al., 2012

\begin{abstract}
با توجه به اينكه توالى زنوم گياه دارويى زنيان در دسترس نيست، نقشهيابى فيزيكى ريزماهوارهها در كروموزومهاى اين كياه امكانيذير نمىباشد. هرجند با توجه به اينكه حداكثر تعداد توالىهاى مشابه بهدست آمده از طريق بلاست مربوط به كياه هويج بود، بنابراين از زنوم هويج براى شناسايى تعداد ريزماهوارهها در كروموزومهاى گياه هويج استفاده گرديد. نكته لازم به ذكر اينكه گياه هويج بهعنوان سردسته و مدل خانواده آيياسه مىباشد و تعداد كروموزوم آن (2n=2x=18) برابر با تعداد كروموزوم گياه دارويى زنيان است (Noori et al., 2017). بيشترين تعداد ريزماهواره به كروموزوم شماره يك و كمترين تعداد به كروموزوم شماره 9 اختصاص يافتند (شكل 0). اين نتيجه ممكن است ناشى از تفاوت تعداد زنهاى كاركردى در كروموزومها و توزيع گسترده زنومى ريزماهوارهها باشد. بيشبينى عملكرد توالىهاى يكيارجه سازى شده داراى ريزماهواره: از ميان ساY V9 توالى يونىزن حاوى تكرارهاى ريزماهواره، تعداد V دستهبندى كاركردى بودند (شكل 7). نمودار تفسير زنشناسى اينترنتى (WEGO) نشان داد كه همه يونىزنها
\end{abstract}

1- Catalytic

2- Secondary metabolic process 


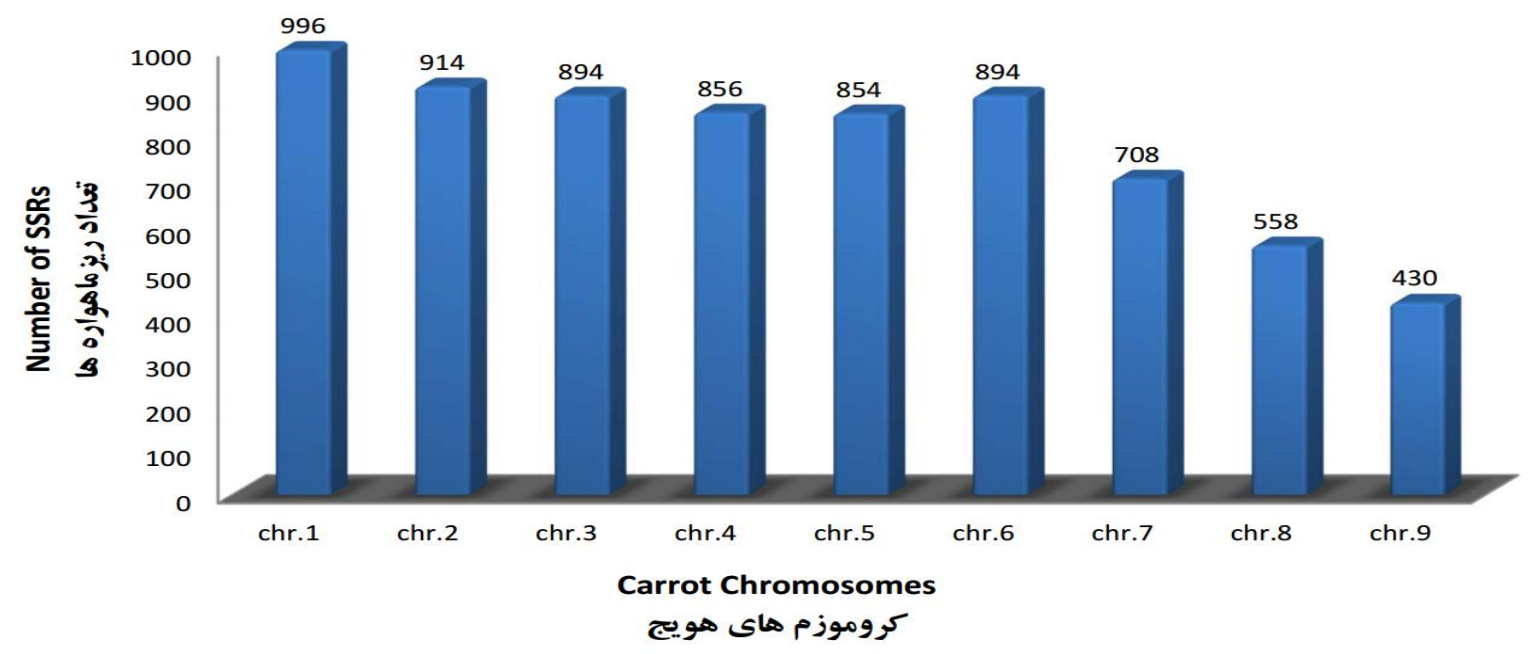

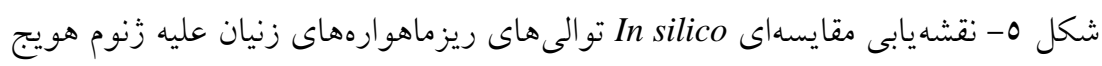

Figure 5. In silico comparative mapping of T. ammi microsatellite sequences on carrot genome

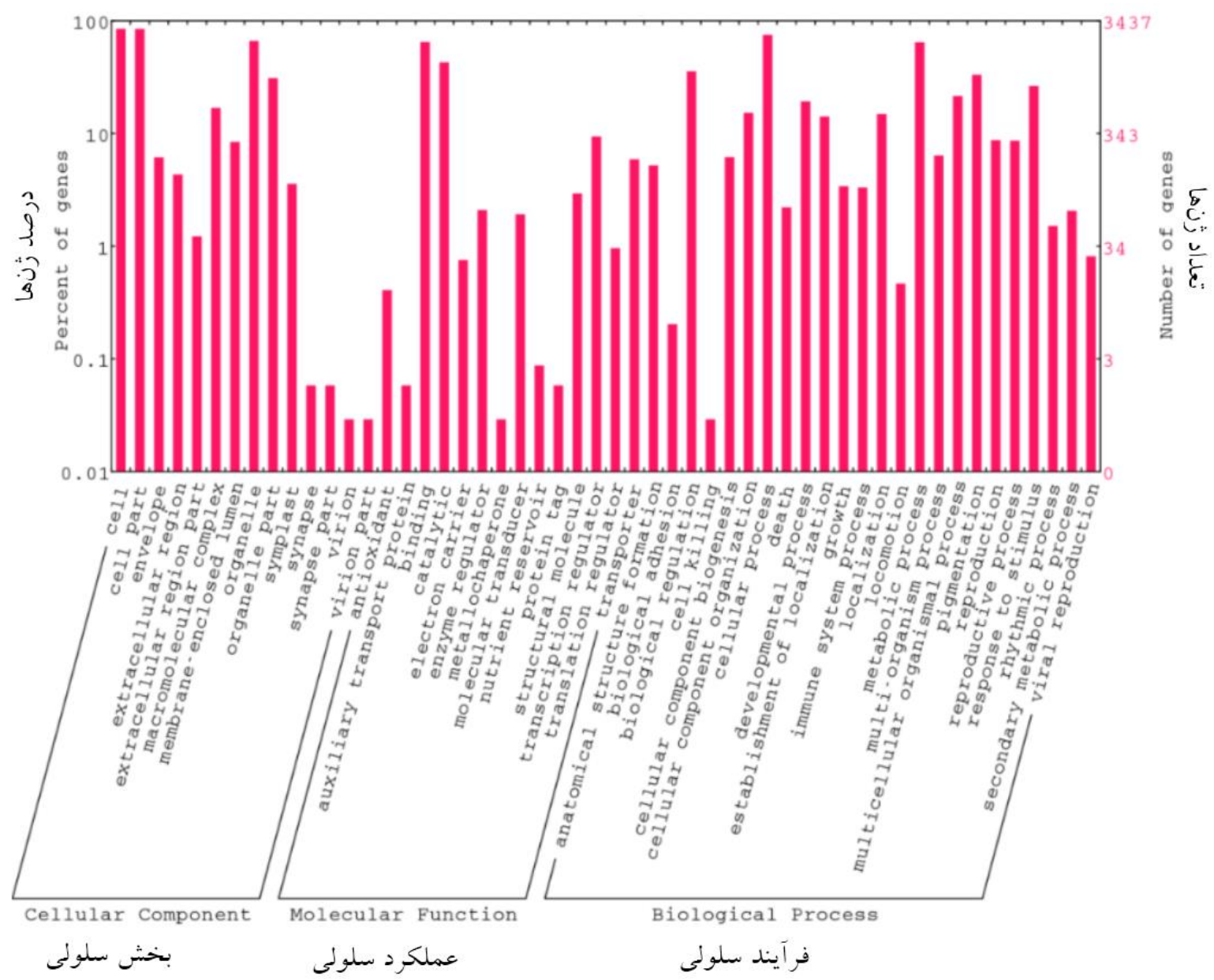

شكل 7- نمودار دستهبندى كاركردى يونىزنهاى يكيار جهازازى شده حاوى ريزماهواره

Figure 6. Functional classification of assembled unigenes containing microsatellites هر ميله درصد يونىزنهاى متصل به گزارهاى GO را نشان مىدهد. محور Y در مبناى لكاريتم •ا مى باشد.

Each bar represents the percentage of unigenes matches to each GO term. Plot with Y axis is in log (10) scale. 
نتايج بهدست آمده از آناليز مسيرهاى بيوشيميايى بهوسيله سرور تفسير اتوماتيك KEGG نشان ماد كه

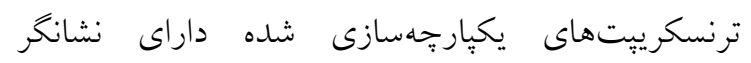

ريزماهواره در · بس مسير بيوشيمايى بايشاه KEGG حضور داشتند. بيشترين ترنسكرييتهاى داراى ريزماهواره، بهترتيب به مسير متابوليكى (ko01100) و مسير بيوسنتز

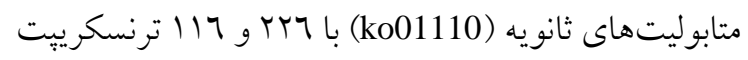

بودند. در مسير بيوسنتز يايه ترينوئيدها (Terpenoid كه نقش بسيار مهمى در توليد backbone biosynthesis تركيبات دارويى گياه زنيان دارد، זا زن از زنهاى مسير شناسايى شدند كه ترنسكرييت مربوط به آنها داراى

$$
\text { ريزماهواره بود (جدول r). }
$$

تنوع ريزماهوارهها در نواحى كدكننده، نواحى غيرترجمه شده در انتهاى 'O، نواحى غير ترجمه شده در انتهاى 'با و اينترونها منجربه تغييراتى در فرآيندهاى رونويسى و و ترجمهاى شله و در نتيجه از طريق تنظيم بيان زن منتهى به تغييرات فنوتييى مى گردد (Li et al., 2004). اين مسأله نشان دهنده اهميت ريزماهوارههاى واقع شده در نواحى كدكننده است. تنوع در ريزماهوارههاى مناطق زنى مىتواند آللهاى مناسبى براى موفقيتهاى حياتى در محيطهاى مختلف ايجاد كند (Li et al., 2004). نشانخرهاى SSR داراى نقش كليدى در تحمل به تنش، متابوليسم و تثبيت كربن، بيوسنتز متابوليتهاى ثانويه، رشد و فتوسنت شناسايى گرديدهاند (Bhandawat et al., 2016).

جدول ب- زنهاى شناسايى شده در مسير بيوسنتز بايه ترينوئيدها (ko00900) داراى ريزماهواره در ترانسكرييتوم كل آذين كياه

$$
\text { دارويى زنيان }
$$

Table 3. Identified genes in terpenoid backbone biosynthesis pathway (Ko00900) containing microsatellite in $T$.

\begin{tabular}{|c|c|c|c|c|c|c|c|c|}
\hline رديف & 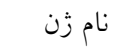 & توصيف زن & كد زن در KEGG & كد آنزيم & يونى ترنسكرييت & طول (bp) & موقعيت (bp) & موتيف \\
\hline No. & Gene name & Gene description & KEGG code & Enzyme code & Unitranscript & Length (bp) & Position (bp) & Motif \\
\hline 1 & HMGCR & $\begin{array}{l}\text { Hydroxymethylglutaryl- } \\
\text { JoA reductase (NADPH }\end{array}$ & K00021 & EC:1.1.1.34 & DN46370_c0_g1_i1 & 2031 & $44-58$ & $(\mathrm{CCA}) 5$ \\
\hline 2 & FDPS & $\begin{array}{l}\text { Farnesyl diphosphate } \\
\text { synthase }\end{array}$ & K00787 & $\begin{array}{l}\text { EC:2.5.1.1 } \\
2.5 .1 .10\end{array}$ & DN45915_c0_g1_i1 & 1544 & $32-46$ & $(\mathrm{CTC}) 5$ \\
\hline 3 & MK & Mevalonate kinase & K00869 & EC:2.7.1.36 & DN54851_c0_g1_i6 & 1536 & $1483-1536$ & $\begin{array}{c}\text { (TG)9aatgagtaat } \\
\text { gtaatgca } \\
\text { atgtaa(TG)6 }\end{array}$ \\
\hline 4 & ispE & $\begin{array}{l}\text { 4-diphosphocytidyl-2 } \\
\text {-C-methyl-D-erythritol } \\
\text { kinase }\end{array}$ & K00919 & EC:2.7.1.148 & DN36615_c0_g1_i1 & 1492 & $1-12$ & (G)12 \\
\hline 5 & ispD & $\begin{array}{l}\text { 2-C-methyl-D-erythritol } \\
\text { 4-phosphate } \\
\text { cytidylyltransferase }\end{array}$ & K00991 & $\mathrm{EC}: 2.7 .7 .60$ & DN42987_c0_g2_i1 & 1661 & $248-262$ & $(\mathrm{TCT}) 5$ \\
\hline 6 & dxs & $\begin{array}{l}\text { 1-deoxy-D-xylulose-5 } \\
\text {-phosphate synthase }\end{array}$ & K01662 & EC:2.2.1.7 & DN30805_c0_g1_i1 & 2495 & $171-158$ & $(\mathrm{GT}) 7$ \\
\hline 7 & idi & $\begin{array}{c}\text { Isopentenyl-diphosphate } \\
\text { Delta-isomerase }\end{array}$ & K01823 & EC:5.3.3.2 & DN41437_c0_g1_i1 & 1325 & $80-94$ & $(\mathrm{GCT}) 5$ \\
\hline 8 & ispH & $\begin{array}{c}\text { H-hydroxy-3-methylbut-^ } \\
\text {-en-1-yl diphosphate } \\
\text { reductase }\end{array}$ & K03527 & EC:1.17.7.4 & DN56344_c1_g1_i2 & 1659 & $63-100$ & (TC) 19 \\
\hline 9 & PCYOX1 & $\begin{array}{l}\text { Prenylcysteine oxidase / } \\
\text { farnesylcysteine lyase }\end{array}$ & K05906 & $\begin{array}{l}\text { EC: } 1.8 .3 .5 \\
1.8 .3 .6\end{array}$ & DN45249_c0_g1_i1 & 1910 & $82-99$ & $(\mathrm{CCA}) 6$ \\
\hline 10 & GGPS & $\begin{array}{c}\text { Geranylgeranyl } \\
\text { diphosphate synthase }\end{array}$ & K13789 & $\begin{array}{l}\text { EC:2.5.1.1 } \\
2.5 .1 .10 \\
2.5 .1 .29\end{array}$ & DN44310_c0_g1_i1 & 1757 & $1481-1495$ & $(\mathrm{AGA}) 5$ \\
\hline 11 & GPS & $\begin{array}{l}\text { Geranyl diphosphate } \\
\text { synthase }\end{array}$ & K14066 & EC:2.5.1.1 & DN35063_c0_g1_i1 & 1804 & $1764-1802$ & (TTA) 13 \\
\hline 12 & FLDH & $\begin{array}{l}\text { NAD+-dependent } \\
\text { farnesol dehydrogenase }\end{array}$ & K15891 & EC:1.1.1.354 & DN39038_c0_g1_i1 & 1020 & $57-71$ & $(\mathrm{CAT}) 5$ \\
\hline
\end{tabular}
ammi inflorescence transcriptome 


$$
\begin{aligned}
& \text { با بوشش كلى توليد كند. بنابر اين تخمين فراوانى تكرارهاى } \\
& \text { ريزماهو ارهها و ويزّكى هاى آنها كمتر دجار اريب مى گردد. } \\
& \text { شناسايى تنوع ريزماهوارهها در ناحيه اخزونى مىتواند در } \\
& \text { فر آيندهاى فيزيولوزيكى و نموى كياه كارايى داشته باشد. } \\
& \text { نتايج اين يزوهش براى نخستين بار توسعه نشانخرهاى } \\
& \text { EST-SSR } \\
& \text { نشانكرها مىتوانند براى انجام تجزيه و تحليلهاى } \\
& \text { نقشههاى بيوستخى و ساخت نقشههاى زنتيكى با تراكم بالا } \\
& \text { در زنيان بهكار روند. شناسايى ريزماهوارههاى موجود در } \\
& \text { توالى زنهاى مرتبط به مسير بيوسنتز متابوليتهاى ثانويه }
\end{aligned}
$$

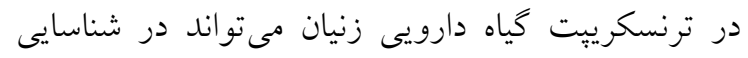

$$
\begin{aligned}
& \text { عوامل موثر تنظيم بيان زنهاى ستز تركيبات دارويى اين } \\
& \text { كياه بسيار موثر باشد. }
\end{aligned}
$$

$$
\begin{aligned}
& \text { وجود اين ريزماهوارهها در ترنسكريتهاى مرتبط به سنتز } \\
& \text { متابوليتهاى ثانويه كياه دارويى زنيان و مطالعه تنوع آنها } \\
& \text { مى تواند در شناسايى عوامل مؤثر در سنتز تركيبات دارويى } \\
& \text { كَياه بسيار مؤثر باشد. مىتوان از ريزماهوارههاى موجود در } \\
& \text { توالىهاى زُنومى، در بهدست آوردن تأثير مستقيم آنها در }
\end{aligned}
$$

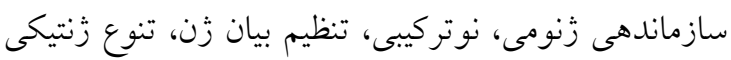

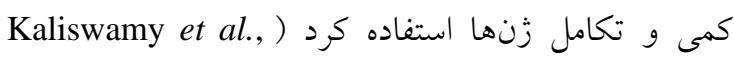

$$
\text { دادههاى ترنسكرييتومى منبع ارزان و روش سريعى جهت }
$$

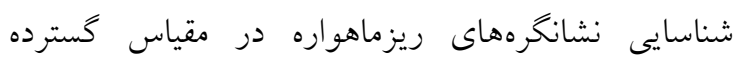$$
\text { مىباشد. در مقايسه با EST كه به بهور عمومى بخش }
$$

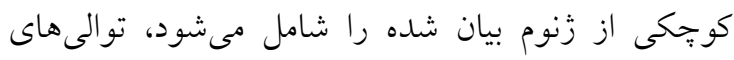$$
\text { ترنسكريتوم مى تواند تعداد زيادى نشانكرههاى ريزماهو اره }
$$

\section{References}

Alagna, F., D'Agostino, N., Torchia, L., Servili, M., Rao, R., Pietrella, M., Giuliano, G., Chiusano, M.L., Baldoni, L. and Perrotta, G. (2009). Comparative 454 pyrosequencing of transcripts from two olive genotypes during fruit development. BMC Genomics 10: 399.

Angeloni, F., Wagemaker, C., Jetten, M., Op den Camp, H., Janssen-Megens, E., Francoijs, K.J., Stunnenberg, H. and Ouborg, N. (2011). De novo transcriptome characterization and development of genomic tools for Scabiosa columbaria L. using next-generation sequencing techniques. Molecular Ecology Resources, 11: 662-674.

Bahmani, K., Izadi-Darbandi, A., Jafari, A.A., Noori, S.A.S. and Farajpour, M. (2012). Assessment of genetic diversity in Iranian fennels using ISSR markers. Journal of Agricultural Science, 4: 79.

Bairwa, R., Sodha, R. and Rajawat, B. (2012). Trachyspermum ammi. Pharmacognosy Reviews, 6: $56-60$.

Bajgain, P., Richardson, B.A., Price, J.C., Cronn, R.C. and Udall, J.A. (2011). Transcriptome characterization and polymorphism detection between subspecies of big sagebrush (Artemisia tridentata). BMC Genomics, 12: 370.

Barakat, A., DiLoreto, D.S., Zhang, Y., Smith, C., Baier, K., Powell, W.A., Wheeler, N., Sederoff, R. and Carlson, J.E. (2009). Comparison of the transcriptomes of American chestnut (Castanea dentata) and Chinese chestnut (Castanea mollissima) in response to the chestnut blight infection. BMC Plant Biology, 9: 51.

Beier, S., Thiel, T., Münch, T., Scholz, U. and Mascher, M. (2017). MISA-web: a web server for microsatellite prediction. Bioinformatics, 33: 2583-2585.

Bhandawat, A., Singh, G., Raina, A.S., Kaur, J. and Sharma, R.K. (2016). Development of genic SSR marker resource from RNA-Seq data in Dendrocalamus latiflorus. Journal of Plant Biochemistry and Biotechnology, 25: 179-190.

Blanca, J., Cañizares, J., Roig, C., Ziarsolo, P., Nuez, F. and Picó, B. (2011). Transcriptome characterization and high throughput SSRs and SNPs discovery in Cucurbita pepo (Cucurbitaceae). BMC Genomics, 12: 104. 
Bräutigam, A., Mullick ,T., Schliesky, S. and Weber, A.P. (2011). Critical assessment of assembly strategies for non-model species mRNA-Seq data and application of next-generation sequencing to the comparison of C3 and C4 species. Journal of Experimental Botany, 62: 3093-3102.

Chen, F., Tholl, D., Bohlmann, J. and Pichersky, E. (2011). The family of terpene synthases in plants: a mid-size family of genes for specialized metabolism that is highly diversified throughout the kingdom. The Plant Journal, 66: 212-229.

Dassanayake, M., Haas, J., Bohnert, H. and Cheeseman, J. (2009). Shedding light on an extremophile lifestyle through transcriptomics. New Phytologist, 183: 764-775.

Farajpour, M., Ebrahimi, M., Amiri, R., Noori, S., Sanjari, S. and Golzari, R. (2011). Study of genetic variation in yarrow using inter-simple sequence repeat (ISSR) and random amplified polymorphic DNA (RAPD) markers. African Journal of Biotechnology, 10: 11137-11141.

Fu, N., Wang, Q. and Shen, H.L. (2013). De novo assembly, gene annotation and marker development using Illumina paired-end transcriptome sequences in celery (Apium graveolens L.). PloS One, 8: e57686.

Futschik, A. and Schlötterer, C. (2010). The next generation of molecular markers from massively parallel sequencing of pooled DNA samples. Genetics, 186: 207-218.

Grabherr, M.G., Haas, B.J., Yassour, M., Levin, J.Z., Thompson, D.A., Amit, I., Adiconis, X., Fan, L., Raychowdhury, R. and Zeng, Q. (2011). Full-length transcriptome assembly from RNA-Seq data without a reference genome. Nature Biotechnology, 29: 644-652.

Guo, S., Liu, J., Zheng, Y., Huang, M., Zhang, H., Gong, G., He, H., Ren, Y., Zhong, S. and Fei, Z. (2011). Characterization of transcriptome dynamics during watermelon fruit development: sequencing, assembly, annotation and gene expression profiles. BMC Genomics, 12: 454.

Hao, D., Ma, P., Mu, J., Chen, S., Xiao, P., Peng, Y., Huo, L., Xu, L. and Sun, C. (2012). De novo characterization of the root transcriptome of a traditional Chinese medicinal plant Polygonum cuspidatum. Science China Life Sciences, 55: 452-466.

Heidari, E.F., Rahimmalek, M., Mohammadi, S. and Ehtemam, M.H. (2016). Genetic structure and diversity of ajowan (Trachyspermum ammi) populations based on molecular, morphological markers, and volatile oil content. Industrial Crops and Products, 92: 186-196.

Hiremath, P.J., Farmer, A., Cannon, S.B., Woodward, J., Kudapa, H., Tuteja, R., Kumar, A., BhanuPrakash, A., Mulaosmanovic, B. and Gujaria, N. (2011). Large-scale transcriptome analysis in chickpea (Cicer arietinum L.), an orphan legume crop of the semi-arid tropics of Asia and Africa. Plant Biotechnology Journal, 9: 922-931.

Kaliswamy, P., Vellingiri, S., Nathan, B. and Selvaraj, S. (2015). Microsatellite analysis in the genome of Acanthaceae: An in silico approach. Pharmacognosy Magazine, 11: 152-156.

Karimbeigi, H., Nazarian-Firouzabadi, F., Khademi, M. and Mousav, E. (2016) Assessment of genetic diversity among some oilseed rape (Brassica nupus L.) plants, using single sequence repeats (SSR) molecular markers. Plant Genetic Researches, 3(1): 45-56 (In Persian).

Kumpatla, S.P. and Mukhopadhyay, S. (2005). Mining and survey of simple sequence repeats in expressed sequence tags of dicotyledonous species. Genome, 48: 985-998.

Li, D., Deng, Z., Qin, B., Liu, X. and Men, Z. (2012). De novo assembly and characterization of bark transcriptome using Illumina sequencing and development of EST-SSR markers in rubber tree (Hevea brasiliensis Muell. Arg.). BMC Genomics, 13: 192.

Li, Y.C., Korol, A.B., Fahima, T. and Nevo, E. (2004). Microsatellites within genes: structure, function, and evolution. Molecular Biology and Evolution, 21: 991-1007.

Li, Y., Sun, C., Luo, H., Li, X., Niu, Y. and Chen, S. (2010). Transcriptome characterization for Salvia miltiorrhiza using 454 GS FLX. Yao xиe xue bao. Acta Pharmaceutica Sinica, 45: 524-529.

Li, Y.C., Korol, A.B., Fahima, T., Beiles, A. and Nevo, E. (2002). Microsatellites: genomic distribution, putative functions and mutational mechanisms: a review. Molecular Ecology, 11: 24532465. 
Lin, X., Zhang, J., Li, Y., Luo, H., Wu, Q., Sun, C., Song, J., Li, X., Wei, J. and Lu, A. (2011). Functional genomics of a living fossil tree, Ginkgo, based on next-generation sequencing technology. Physiologia Plantarum, 143: 207-218.

Lu, F.H., Cho, M.C. and Park, Y.J. (2012). Transcriptome profiling and molecular marker discovery in red pepper, Capsicum annuum L. TF68. Molecular Biology Reports, 39: 3327-3335.

Luo, H., Sun, C., Sun, Y., Wu, Q., Li, Y., Song, J., Niu, Y., Cheng, X., Xu, H. and Li, C. (2011). Analysis of the transcriptome of Panax notoginseng root uncovers putative triterpene saponinbiosynthetic genes and genetic markers. BMC Genomics, 12: S5.

Mirzahosseini, S.M., Noori, S.A.S., Amanzadeh, Y., Javid, M.G. and Howyzeh, M.S. (2017). Phytochemical assessment of some native ajowan (Therachyspermum ammi L.) ecotypes in Iran. Industrial Crops and Products, 105: 142-147.

Modareskia, M., Darvishzadeh, R., Hassani, A. and Kholghi, M. (2013). Molecular diversity within and between Ajowan (Carum copticum L.) populations based on inter simple sequence repeat (ISSR) markers. Journal of Plant Molecular Breeding, 1: 51-62.

Moriya, Y., Itoh, M., Okuda, S., Yoshizawa, A.C. and Kanehisa, M. (2007). KAAS: an automatic genome annotation and pathway reconstruction server. Nucleic Acids Research, 35: W182-W185.

Noori, S.A.S., Norouzi, M., Karimzadeh, G., Shirkool, K. and Niazian, M. (2017). Effect of colchicine-induced polyploidy on morphological characteristics and essential oil composition of ajowan (Trachyspermum ammi L.). Plant Cell, Tissue and Organ Culture (PCTOC), 130(3): 543551.

Parida, S.K., Pandit, A., Gaikwad, K., Sharma, T.R., Srivastava, P.S., Singh, N.K. and Mohapatra, T. (2010). Functionally relevant microsatellites in sugarcane unigenes. BMC Plant Biology, 10: 251.

Primmer, C.R. (2009) .From conservation genetics to conservation genomics. Annals of the New York Academy of Sciences, 1162: 357-368.

Sadati, S., Sadat-Noori, S.A., Ramshini, H., Soltani, E. and Foghi, B. (2016). Towards conservation and breeding of Ajowan (Trachyspermum ammi) by assessing ISSR, morphological traits and germination variability. Iranian Journal of Genetics and Plant Breeding, 5: 8-21.

Sargazi, A. (2016). Genetic diversity of some population of medicinal Ajowan (Trachyspermum copticum) using RAPD marker. M.Sc. Thesis. Faculty of Agriculture, University of Zabol, Zabol, Iran (In Persian).

Shuorvazdi, A., Mohammadi, S.A., Norozi, M. and Sadeghzadeh, B. (2014) Molecular analysis of genetic diversity and relationships of barley landraces based on microsatellite markers. Plant Genetic Researches, 1(1): 51-64 (In Persian).

Soltani Howyzeh, M., Sadat Noori, S.A. and Shariati, J.V. (2018a). Essential oil profiling of Ajowan (Trachyspermum ammi) industrial medicinal plant. Industrial Crops and Products, 119: 255-259.

Soltani Howyzeh, M., Sadat Noori, S.A,. Shariati J.V. and Niazian, M. (2018b). Essential oil chemotype of Iranian Ajowan (Trachyspermum ammi L.). Journal of Essential Oil Bearing Plants, 21: 273-276.

Strickler, S.R., Bombarely, A. and Mueller, L.A. (2012). Designing a transcriptome next-generation sequencing project for a nonmodel plant species1. American Journal of Botany, 99: 257-266.

Vasemägi, A., Nilsson, J. and Primmer, C.R. (2005). Expressed sequence tag-linked microsatellites as a source of gene-associated polymorphisms for detecting signatures of divergent selection in Atlantic salmon (Salmo salar L.). Molecular Biology and Evolution, 22: 1067-1076.

Wei, W., Qi, X., Wang, L., Zhang, Y., Hua, W., Li, D., Lv, H. and Zhang, X. (2011). Characterization of the sesame (Sesamum indicum L.) global transcriptome using Illumina paired-end sequencing and development of EST-SSR markers. BMC Genomics, 12: 451.

Xu, M., Liu, X., Wang, J.W., Teng, S.Y., Shi, J.Q., Li, Y.Y. and Huang, M.R. (2017). Transcriptome sequencing and development of novel genic SSR markers for Dendrobium officinale. Molecular Breeding, 37: 18. 


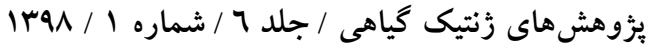

Zhang, J., Liang, S., Duan, J., Wang, J., Chen, S., Cheng, Z., Zhang, Q., Liang, X. and Li, Y. (2012). De novo assembly and characterisation of the transcriptome during seed development, and generation of genic-SSR markers in peanut (Arachis hypogaea L.). BMC Genomics, 13: 90. 


\title{
Large Scale Identification of SSR Molecular Markers in Ajowan (Trachyspermum ammi) Using RNA Sequencing
}

\author{
Mehdi Soltani Howyzeh ${ }^{1,2}$, Seyed Ahmad Sadat Noori ${ }^{3, *}$, Vahid Shariati ${ }^{4}$ and \\ Mahboubeh Amiripour ${ }^{1}$
}

1- Former Ph.D. Student, Department of Agronomy and Plant Breeding Sciences, College of Aburaihan, University of Tehran, Tehran, Iran

2- Instructor, Department of Genetic and Plant Breeding, Islamic Azad University Ahvaz Branch, Ahvaz, Iran

3- Professor, Department of Agronomy and Plant Breeding Sciences, College of Aburaihan, University of Tehran, Tehran, Iran

4- Assistant Professor, Department of Plant Molecular Biotechnology and NIGEB Genome Center, National Institute of Genetic Engineering and Biotechnology, Tehran, Iran

(Received: January 6, 2018 - Accepted: May 19, 2018)

\begin{abstract}
The medicinal plant, Trachyspermum ammi is a rich source of active pharmaceutical ingredients with pharmaceutics effects. Microsatellite markers play a key role in the genome and gene expression, especially in secondary metabolite biosynthesis in medicinal plants. For the first time, transcriptome sequencing of this herb medicine was carried out to identify the microsatellite markers of this species. After pair-end sequencing with the Illumina HiSeq 2000 platform, the quality of the reads was evaluated by FastQC software, trimming was performed by Trimmomatic software and De novo assembly was done with Trinity software. In this study, 11,468 unitranscripts (7913 unigenes) were found to contain 13593 potential microsatellites. The most abundant microsatellite types were di-nucleotide $(67 \%)$ and tri-nucleotide $(24 \%)$. Also, six repeated SSRs were the most abundant repeats. The predominant sequence was AG / CT (31\%). Sixty-five percent of SSRs were belonged to class II (10-20 nucleotides) and 35\% to class I (more than 20 nucleotides). The frequency of SSRs found to be approximately one per $10.1 \mathrm{kB}$ of assembled sequence. More than 57 percent of unigenes containing SSRs were blasted with carrot genome. This showed that T. ammi was an Apiaceae family member and had a high similarity to the carrot genome. A total of 3437 unigenes (43\%) were categorized functionally, which among them 2219 unigenes $(64.6 \%)$ belonged to the "metabolic process" category and 71 unigenes $(1.2 \%)$ were assigned to the "secondary metabolic process". In this study, 12 genes were detected in the terpenoid backbone biosynthesis pathway, that their transcripts were containing a microsatellite. These SSRs probably contribute to the genes expression and the biosynthesis of metabolites, especially secondary metabolites. The development of these markers can be used for future studies of marker-assisted selection, genetic diversity and construct genetic maps in this medicinal plant.
\end{abstract}

Keywords: Apiaceae, Terpenoids, Transcriptome, Secondary metabolic 